\title{
LEVELS OF THYROID AND THYROTROPHIC HORMONES IN THE BLOOD OF FRIESIAN COWS AT VARIOUS REPRODUCTIVE STAGES
}

\author{
F. A. SOLIMAN, H. NASR AND K. ZAKI \\ Department of Animal Physiology and Department of Obstetrics and Gynecology, Faculty \\ of Veterinary Medicine, Cairo University, Giza, Egypt, U.A.R.
}

(Received 11th April 1963)

\begin{abstract}
Summary. Thyroid and thyrotrophic hormone levels in the blood of Friesian cows were determined during the oestrous cycle, at different months of pregnancy and 10 days after parturition.

During the oestrous cycle there was an increase in the thyroid hormone level at oestrus accompanied by a decrease in the level of thyroidstimulating hormone. The thyroid hormone content of blood was low during dioestrus while the thyrotrophic hormone was high.

No variation in thyroid hormone level was noticed during pregnancy, except for an increase during the 9th month. The level of thyrotrophic hormone was maintained at a comparatively high level during the first 4 months of pregnancy.

After parturition the level of thyroid hormone was similar to that observed during dioestrus, while there was an increase in the level of thyrotrophic hormone.
\end{abstract}

\section{INTRODUCTION}

The relationship between the thyroid, the ovary and the pituitary gland during the reproductive cycle is intricate. There is evidence that thyroid activity shows a cyclic pattern during the oestrous cycle and it has been reported that it is maximal during oestrus in rats (Hunt, 1944; Soliman \& Reineke, 1954 a, b; Feldman, 1956), rabbits (Soliman \& Ghanem, 1956), ewes (Ghanem \& Soliman, 1956; Robertson \& Falconer, 1961) and buffaloes (Soliman \& Said, 1960; Abdo, 1962). On the other hand, maximal activity of the thyroid is attained during the luteal phase in guinea-pigs (Chouke, Friedman \& Loeb, 1935).

The results recorded regarding thyroid activity during pregnancy are rather conflicting. For example, it has been reported that pregnancy and parturition can follow a normal course in thyroidectomized rabbits (Krohn, 1951) and cattle (Spielman, Peterson \& Fitch, 1943; Spielman, Peterson, Fitch \& Pomeroy, 1945). Moreover it has been recorded that no significant variations in thyroid function were observed during pregnancy in sheep (Henneman, Reineke \& Griffin, 1955) and goats (Flamboe \& Reineke, 1959). In contrast it 
was reported that thyroid activity is increased during pregnancy in rats (Danforth \& Loumos, 1936) and women (Farraris \& Scorta, 1955; Stoffer, Koenek, Chesky \& Helwig, 1957). Recent studies on domestic animals have shown increased levels of protein-bound iodine during pregnancy (Sørensen, 1956). Furthermore, low plasma protein-bound iodine values were encountered in cows with a history of many matings without conception or with a high incidence of abortion (Lewis \& Ralston, 1953).

The aim of the present investigation was the simultaneous study of the levels of thyrotrophic and thyroid hormones in the blood of Friesian cows during the oestrous cycle, at different months of pregnancy and in the first few days after parturition.

\section{MATERIALS AND METHODS}

Blood samples were obtained from 112 Friesian cows, divided into groups of eight animals representing oestrus, dioestrus, different months of pregnancy, and a period of 10 days after parturition.

Each blood sample was allowed to clot and the serum was separated by centrifugation at $4000 \mathrm{rev} / \mathrm{min}$ for $15 \mathrm{~min}$. Equal volumes of sera from cows at the same reproductive state were pooled. Thyrotrophic hormone was separated from the serum by adding acetone to the sera to reach a concentration of about $85 \%$ acetone (Fellinger, 1936). The precipitated serum proteins were then washed three times with acetone-ether mixture $(1: 1 \mathrm{v} / \mathrm{v})$ to remove the steroid hormones. Normal saline solution was then added to the pulverized precipitate to bring it back in solution to the original volume of serum.

The thyrotrophic hormone content of cows' sera was determined by the use of the 1-day-old male chick assay method (Bergman \& Turner, 1939). Two hundred and twenty-five 1-day-old chicks were divided into fifteen groups of fifteen. One group was injected with $0.5 \mathrm{ml}$ of saline solution for 4 successive days and kept as control. The other fourteen groups were injected with sera from cows at oestrus, dioestrus, pregnancy and after parturition. Each chick received a daily subcutaneous injection of $0.5 \mathrm{ml}$ of serum for 4 successive days. Twentyfour hours after the last injection the chicks were killed with ether and their thyroid glands were weighed with a torsion balance and expressed in $\mathrm{mg} / 100 \mathrm{~g}$ body weight.

For the assay of thyroid hormone level in cows' sera, the stasis tadpole method adopted by D'Angello \& Gordon (1950) was used. Tadpoles were divided into groups of twenty and injected intraperitoneally on alternate days. One group was injected with five intraperitoneal injections of $0.01 \mathrm{ml}$ of saline solution. The other groups were injected with five doses of $0.01 \mathrm{ml}$ of serum obtained from cows at various reproductive stages. Twenty-four hours after the last injection the tadpoles were killed with chloroform, then fixed in $80 \%$ alcohol. The hind limbs were then measured with a micrometer and their average length was used as a criterion of the thyroid hormone level in the corresponding samples of serum.

For evaluation of the significance of differences between the means, the analysis of variance was performed and the ' $F$ ' ratio was calculated. 


\section{RESULTS}

The results obtained are recorded in Tables 1 and 2.

\section{TABLE 1}

LEVELS OF THYROTROPHIC AND THYROID HORMONES IN THE BLOOD OF COWS DURING THE OESTROUS GYGLE AND PREGNANGY, AND AFTER PARTURITION

\begin{tabular}{|c|c|c|}
\hline & $\begin{array}{c}\text { Thyrotrophic } \\
\text { hormone }\end{array}$ & $\begin{array}{l}\text { Thyroid } \\
\text { hormone }\end{array}$ \\
\hline Type of serum & $\begin{array}{c}\text { Chick thyroid wt. } \\
\text { (mg/100 g body } \\
\text { wt. })\end{array}$ & $\begin{array}{l}\text { Average length of } \\
\text { tadpole hind limbs } \\
\text { ( } \mathrm{mm})\end{array}$ \\
\hline $\begin{array}{l}\text { Oestrous cycle } \\
\text { Oestrus } \\
\text { Dioestrus }\end{array}$ & $\begin{array}{r}6 \cdot 80 \pm 1 \cdot 32 \\
10 \cdot 38 \pm 0.95\end{array}$ & $\begin{array}{l}3.48 \pm 0.24 \\
1.64 \pm 0.14\end{array}$ \\
\hline $\begin{array}{l}\text { Pregnancy } \\
\text { 1st month } \\
\text { 2nd month } \\
\text { 3rd month } \\
\text { 4th month } \\
\text { 5th month } \\
\text { 6th month } \\
\text { 7th month } \\
\text { 8th month } \\
\text { 9th month }\end{array}$ & $\begin{array}{r}10.35 \pm 1.28 \\
11 \cdot 18 \pm 0.70 \\
8.80 \pm 0.78 \\
11 \cdot 10 \pm 0.53 \\
7.16 \pm 0.60 \\
6.90 \pm 0.40 \\
7.92 \pm 1.22 \\
6.49 \pm 0.86 \\
7.19 \pm 0.59\end{array}$ & $\begin{array}{l}2 \cdot 19 \pm 0 \cdot 14 \\
2 \cdot 20 \pm 0 \cdot 22 \\
2 \cdot 57 \pm 0 \cdot 35 \\
2 \cdot 11 \pm 0 \cdot 26 \\
2 \cdot 08 \pm 0 \cdot 17 \\
1 \cdot 89 \pm 0 \cdot 20 \\
2 \cdot 05 \pm 0 \cdot 17 \\
1 \cdot 87 \pm 0 \cdot 14 \\
2 \cdot 88 \pm 0.41\end{array}$ \\
\hline $\begin{array}{l}\text { After parturition } \\
1 \text { to } 3 \text { days } \\
4 \text { to } 7 \text { days } \\
8 \text { to } 10 \text { days }\end{array}$ & $\begin{array}{l}6.93 \pm 0.55 \\
8.84 \pm 0.98 \\
8.64 \pm 0.14\end{array}$ & $\begin{array}{c}1.85 \pm 0.22 \\
- \\
1.90 \pm 0.12\end{array}$ \\
\hline $\begin{array}{l}\text { Control saline } \\
\text { solution }\end{array}$ & $5 \cdot 78 \pm 0 \cdot 77$ & $0.86 \pm 0.02$ \\
\hline
\end{tabular}

TABLE 2

ANALYSIS OF VARIANGE OF DATA PRESENTED IN TABLE 1

\begin{tabular}{l|c|cr|l}
\hline \multicolumn{1}{c|}{ Hormone } & Fratio & \multicolumn{2}{|c|}{ d.f. } & Significance \\
\hline Thyrotrophic & $5 \cdot 10$ & 14 & 98 & $P=0.01$ \\
Thyroid & 9.66 & 14 & 223 & $P=0.01$ \\
\hline
\end{tabular}

\section{OESTROUS GYCLE}

The level of the thyroid hormone was at its highest in the serum of oestrous cows as compared with its level in dioestrous ones. The level of thyrotrophic 
hormone was inversely proportional to the thyroid hormone level. The thyrotrophic hormone was much higher during dioestrus (Table 1 and Text-fig. 1).

\section{PREGNANGY}

The level of thyroid hormone did not show any statistically significant variation during pregnancy except in the 9th month, when it increased. The thyrotrophic hormone level was significantly higher during the first 4 months of pregnancy than during the following months till parturition.

\section{AFTER PARTURITION}

During the 10 days following parturition the thyroid hormone level was decreased. Beginning with the 4th day after parturition, the level of thyrotrophic hormone showed a significant rise.

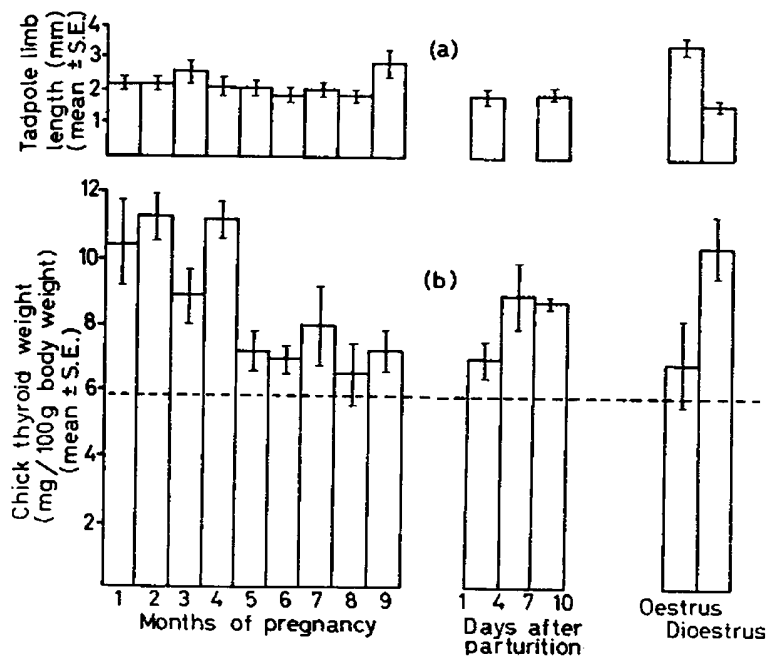

Text-Fig. 1. Thyroid hormone level (a) and thyrotrophic hormone level (b) in the blood of cows. The dashed line in (b) represents the control level of the saline solution.

\section{DISCUSSION}

The relationship between the thyroid and pituitary glands is generally regarded as being governed by a feed-back mechanism (D'Angelo \& Roland, 1956; Bottari, 1961). The changes we observed at different stages of the oestrous cycle and early pregnancy are compatible with this hypothesis, but the changes observed during the second half of pregnancy are less easily interpreted in this way. The significant drop in the level of thyrotrophic hormone in the second half of pregnancy as compared with the first half, is conceivably related to a lowered metabolic rate in the mother. It has been shown that pregnancy does not increase the metabolic rate of the pregnant cow apart from what is accounted for by an increase in that of the uterus and its contents (P. H. Sørensen, 1958cited by Moustgaard, 1959).

The level of thyroid hormone in the blood of cows was increased during the 9th month of pregnancy. Pipes, Premachandra \& Turner (1958) also noticed an 
increased thyroid activity during late pregnancy in cows. This phenomenon was observed in cats by Herlant \& Racadot (1957), in gilts by Lucas, Brunstadt \& Fowler (1958) and in buffaloes by Abdo (1962).

Beginning with the 4 th day after parturition, there was a relatively increased level of thyrotrophic hormone suggesting that its role is to activate the thyroid to keep it on a par with the increased utilization of thyroid hormone at the onset of milk secretion.

\section{REFERENCES}

AвDo, M. S. (1962) Hormonal variations in the blood of buffaloes during pregnancy. M.D.Vet. thesis, Cairo University.

Bergman, A. J. \& Turner, C. W. (1939) A comparison of the guinea-pig and chick thyroid in the assay of the thyrotrophic hormone. Endocrinology, 24, 656.

BotTARI, P. M. (1961) Anterior pituitary thyrotrophit hormone. Modern Trends in Endocrinology. Ed. H. Gardiner-Hill. Butterworths, London.

Ghouke, K. S., Friedman, H. \& Loeb, L. (1935) Proliferative activity of the thyroid gland of the female guinea-pig during the sexual cycle. Anat. Rec. 63, 131.

DANFORTH, D. N. \& Loumos, S. (1936) Effect of administration of desiccated thyroid during pregnancy in the albino rat. Proc. Soc. exp. Biol., N.Y. 34, 870.

D'Angelo, S. A. \& Gordon, A. S. (1950) The simultaneous detection of thyroid and thyrotrophic hormones in vertebrate sera. Endocrinolog $y, 46,39$.

D'Angelo, S. A. \& Roland, E. T. (1956) Pituitary-thyroid function in rats with hypothalamic lesions. Endocrinology, 59, 563 .

Farraris, G. M. \& SCORTA, A. (1955) Compartamento di alcuni tests di funzione tiroidea in gravidanza e in puerperio. Minerva ginec. 7, 308.

Feldman, J. P. (1956) Effect of estrus and estrogen on thyroid uptake of $\mathrm{I}^{131}$ in rats. Endocrinology, $58,327$.

Fellinger, K. (1936) Klinische und experimentelle Untersuchungen über das Verhalten und die Bedeutung des thyrotropen Hormons im Blute. Arch. inn. Med., Wien, 29, 375.

Flamboe, E. E. \& Reineke, E. P. (1959) Estimation of thyroid secretion rates in dairy goats and measurement of $\mathrm{I}^{131}$ uptake and release with regard to age, pregnancy, lactation and season of the year. F. Anim. Sci. 18, 1135 .

Ghanem, Y. S. \& Soliman, F. A. (1956) Thyrotrophic and gonadotrophic hormone level in the blood of Egyptian (fat-tailed) sheep, during different reproductive stages. Brit. vet. med. F. 112, 462.

Henneman, H. A., Reineke, E. P. \& Grifrin, S. A. (1955) The thyroid secretion rate of sheep as affected by season, age, breed, pregnancy and lactation. 7. Anim. Sci. 14, 419.

Herlant, M. \& Racadot, J. (1957) Le lobe anterieur de l'hypophyse de la chatte au cours de la gestation et de la lactation. Arch. Biol., Paris, 68, 217.

Hunt, T. E. (1944) Mitotic activity in the thyroid gland of female rats. Anat. Rec. 90, 133.

Kronn, P. L. (1951) The effect of thyroidectomy on reproduction in the female rabbit. $\mathcal{F}$. Endocrin. $7,307$.

Lewis, R. C. \& Ralston, N. P. (1953) Protein-bound iodine levels in dairy cattle plasma. F. Dairy Sci. $36,33$.

Lucas, J. J., Brunstadt, G. E. \& Fowler, S. H. (1958) The relationship of altered thyroid activity to various reproductive phenomena in gilts. $\mathcal{F}$. Endocrin. 17, 45.

MoustgaARD H. (1959) Nutrition and reproduction in domestic animals. Reproduction in Domestic Animals, vol. II, p. 169. Eds. H. H. Gole and P. T. Cupps. Academic Press, New York.

Pipes, G. W., Premachandra, B. N. \& Turner, G. W. (1958) Effect of estrogen and progesterone on thyroid function of cattle. F. Dairy Sci. 41, 1387.

Robertson, H. A. \& Falconer, I. R. (1961) Reproduction and thyroid activity. F. Endocrin. 22, 133.

Soliman, F. A. \& GHANEM, T. S. (1956) Levels of thyrotrophic and gonadotrophic hormones in the blood of mature and immature female rabbits. Nature, Lond. 178, 745.

Soliman, F. A. \& Reineke, E. P. (1954a) Changes in uptake of radioactive iodine by the thyroid of the rat during the estrous cycle. Amer. F. Physiol. 178, 89.

SOLIMAN, F. A. \& ReINEKe, E. P. (1954b) Oxygen consumption, basal temperature and body weights of female rats as compared with the stages of the oestrous cycle. Egypt. vet. med. F. 1, 37.

Soliman, F. A. \& SAID, A. H. (1960) Hormonal changes in the blood of cows and buffaloes during the estrous cycle. Proc. 1st Arab. vet. Congr., Cairo, p. 235.

SøRENSEN, P. H. (1956) Variation in the concentration of protein-bound iodine in the blood of cattle and pigs. K. VetHojsk. Arsskr. p. 64. 
Spielman, A. A., Peterson, W. E. \& Fitch, J. B. (1943) The effect of thyroidectomy upon the lactation of the bovine. J. Dairy Sci. 26, 745.

Spielman, A. A., Peterson, W. E., Frrch, J. B. \& Pomeroy, B. S. (1945) General appearance, growth and reproduction of the thyroidectomized bovine. J. Dairy Sci. 28, 329.

Stoffer, R. P., Koeneke, I. A., Chesky, V. E. \& Hellwig, C. A. (1957) The thyroid in pregnancy. Amer. F. Obst. Gynec. 74, 300. 